\title{
Pamięć, czyli farmakon
}

Agata Bielik-Robson

TEKSTY DRUGIE 2016, NR 6, S. 68-78

DOI: $10.18318 /$ td.2016.6.5

o jest lepsze dla życia: pamiętać czy nie pamiętać? Czy, jak twierdził w swoim wystąpieniu Jan Sowa, wszelka pamięć jest konserwatywna, a więc tylko zapatrzona w przeszłość, a jako taka stanowi przeszkodę dla myślenia o przyszłości? Czy może jest odwrotnie i tylko odpowiednio zapamiętana przeszłość otwiera drogę odpowiedzialnym projektom futurystycznym? Kto ma więc rację: Nietzsche, piętnując szkodliwość historii dla życia; Mao, który w imię świetlanej przyszłości kazał zburzyć wszystkie pomniki; Jan Sowa, który w polskiej obecnej pamięci o komunizmie widzi tylko kaganiec nałożony na śmiałe utopistyczne myślenie - czy raczej ci, dla których odpowiednio skonstruowana pamięć stanowi konieczny warunek odpowiedzialnej wizji przyszłości? Oto pytania, wokół których chciałabym ułożyć mój esej.

\section{Wieczna teraźniejszość traumy, czyli patologie polskiej pamięci}

Zacznijmy od złego rodzaju pamiętania, który istotnie blokuje wszelkie otwarcie na przyszłość. To temat
Agata Bielik-Rob-

son - mieszka w Warszawie i Nottingham. Pracuje w Instytucie Filozofii i Socjologii PAN oraz jako profesor Jewish Studies na Wydziale Teologii i Religioznawstwa w University of Nottingham. Zajmuje się współczesną filozofią podmiotu, teorią literatury, filozofią religii, oraz myślą postsekularną ze szczególnym uwzględnieniem dziedzictwa żydowskiego. Kontakt: abielik@ifispan.waw.pl 
znanej rozprawy Nietzschego $O$ pożytkach i szkodliwości pamięci dla życia, którą można czytać na dwa sposoby: albo jako jednoznaczną napaść na „pasożyta pamięci", który zagnieżdża się w ludzkim umyśle, wysysając zeń soki witalne, albo - bardziej dialektycznie - jako subtelną wskazówkę pozwalającą odróżnić pamięć patologiczną od pamięci życiodajnej'. Pójdę tym drugim tropem, nawet jeśli wbrew intencjom Nietzschego: oprócz bowiem pamięci "antykwarycznej", która przytłacza psychikę zobowiązaniami wobec tego, co było i czego ślady pamięć usiłuje zachować, istnieje też pamiętanie aktywne, którego imperatywem jest odpowiedzialność wobec przyszłości. Gdy Nietzsche definiuje człowieka jako istotę, która może składać obietnice, czyni to tylko ze względu na jej zdolność od odpowiedniego pamiętania. Niebagatelna bowiem część owych obietnic przybiera formę negatywną - czyli „nigdy więcej!". Jedynie więc dobrze skonstruowana pamięć sprawia, że możemy wyzwolić się z kręgu jałowych powtórzeń i wyjść z niewoli złych projektów. Wbrew temu, co twierdził Marks, nie każda tragedia powtarza się tylko jako farsa; najczęściej powtarza się jako po prostu kolejna tragedia.

Idea, że dobra pamięć pozwala na exodus z błędnego koła powtórzeń, pojawia się w eseju Freuda Poza zasada przyjemności $i^{2}$. W obu tych tekstach, i Nietzschego, i Freuda, dochodzi do głosu pewien paradoks: dobre, odpowiednie pamiętanie okazuje się częściowo zapomnieniem, gdzie zapomnienie, ta Nietzscheańska aktive Vergessenheit, to nade wszystkim zdolność do nabrania dystansu do tego, co było, jako właśnie przeszłości, czyli czegoś, co już nie istnieje. Pamięć właściwa zatem korzystałaby dialektycznie z mocy zapominania, która oddala to, co przeszłe, od żywego spektrum teraźniejszości, nie pozwalając tym samym, by widma przeszłych zdarzeń nakładały się na czas przeżywany tu i teraz. Podczas gdy Nietzsche nazywa wiecznie obecną przeszłość „śmiercionośną siłą”, Freud mówi w tym kontekście o przymusie powtarzania, który także umieszcza po stronie popędu śmierci. Przeszłość, która nie może stać się przeszłością i nieustannie powraca w swojej widmowej aktualności, staje się głównym narzędziem Tanatosa, który metodycznie zabija żywą psyche, odbierając jej podstawową witalną umiejętność bycia-w-czasie, uczestnictwa w jego ciągłej przemianie.

Patologia pamięci polegałaby więc na podtrzymywaniu przeszłości jako wiecznie teraźniejszej - i na tym też zasadza się najbardziej chorobliwy

1 Por. F. Nietzsche Niewczesne rozważania, przeł. M. Łukasiewicz, Znak, Kraków 1996.

2 Por. Z. Freud Poza zasadą przyjemności, przeł. J. Prokopiuk, PWN, Warszawa 1994. 
aspekt polskiej pamięci historycznej. Kilku polskich badaczy już zastosowało psychoanalizę do interpretacji sytuacji społecznej w Polsce (Paweł Dybel, Piotr Augustyniak, Szymon Wróbel, Jan Sowa) i moja wykładnia polskiej pamięci patologicznej jako przymusu powtarzania dobrze wpisuje się w ten trend. Wydaje się bowiem, że Polska prawicowa polityka historyczna stawia na patologiczny mechanizm Wiederholungszwang, który aktywnie przeciwstawia się przepracowaniu przeszłości jako przeszłości właśnie. W tanatycznym systemie powtórzenia, jaki proponuje, chodzi wprost o zablokowanie pracy nad pamięcią, jego istotą okazuje się bowiem wieczna teraźniejszość traumy. Nie tylko zatem mamy tu do czynienia z memorologiczną patologią, ale z patologią obróconą w metodyczną narodową propagandę, której zadaniem jest uniemożliwienie krytycznego procesu Durcharbeiten; to hiperpatologia, która świadomie lansuje się jako jedyny model zdrowia. W tym szaleństwie, niestety, jest metoda.

Doskonałą analizę tej szaleńczej metody przedstawiła w swojej prezentacji Magdalena Saryusz-Wolska, więc ja tylko dokonam psychoanalitycznego podsumowania. Po pierwsze, jak trafnie wskazała badaczka, pamięć ta stawia na obrazy: pokazane przez Saryusz-Wolską okładki prawicowo-patriotycznych periodyków w rodzaju „Do Rzeczy” albo „W Sieci” celowo zaburzają linearne poczucie upływu czasu. Jarosław Kaczyński przebrany w mundur Piłsudskiego albo muzułmańscy „terroryści” wklejeni zamiast Niemców w znane z czasów wojny zdjęcie polskiej granicy to chwyty służące efektowi powtórzenia: wiecznego powrotu tego samego, w którym Polska zawsze musi bronić się przed zagrożeniami z zewnątrz. Trauma zagrożenia i kolankowy odruch obronny to model ptolemejskiej niezmienności, w którym zastygła polska historia, przez co dokonała się całkowita negacja upływu czasu. Podczas gdy historia opowiedziana zawiera, jak każda skomplikowana opowieść, napięcia, perypetie i zwroty akcji, historia zamarła w obrazach jest tylko katalizatorem prostego ciągu skojarzeń, który uruchamia się automatycznie. Podczas gdy narracja należy do domeny świadomego Ja, które potrafi być-w-czasie, ta seria obrazów, jakie podsuwa nam prawicowa polityka historyczna, należy bez reszty do nieświadomości, której żywiołem jest bezczas, nunc stans, wieczna teraźniejszość.

W eseju tym trzymać się będę psychoanalizy, ale na chwilę uczynię dygresję. Choć Freud znakomicie opisuje negację czasowości, jaka zachodzi w obszarach nieświadomego, to zbiorowe efekty tej negacji jeszcze lepiej diagnozuje fenomenologia religii, czyli dziedzina stworzona przez Mirceę Eliadego. Eliade wprost definiuje sacrum jako sferę, w której 
dochodzi do zawieszenia temporalności i którą wyznacza illud tempus: „ten czas”, moment uprzywilejowanego wydarzenia, które odtąd będzie się rytualnie powtarzać, unieważniając czas wszystkich innych profanicznych zdarzeń ${ }^{3}$. Polski narodowy rok liturgiczny zbudowany jest dokładnie wedle Eliadowskiego modelu cyklicznego, którego celem jest odebranie historii linearności: 1 sierpnia zawsze wybucha powstanie, 1 września zawsze zaczyna się wojna, a 10 kwietnia zawsze spada prezydencki samolot (to nowe święto, przez nową władzę nieustannie podklejane pod starsze tradycje, już wkrótce uzyska ten sam sakralny status bezczasu). Zresztą zestawienie Freuda z Eliadem nie jest li tylko dygresyjne; w istocie ich wizje wiecznej teraźniejszości są doskonale symetryczne. To, co Freuda przeraża - zawłaszczenie czasu linearnego przez powtarzalne Wydarzenie oddziałujące z siłą traumy - Eliade bierze za pozytywne kryterium sakralności, którym jest właśnie negacja czasu. To, co Freud usiłuje zmienić, poddając przymus powtarzania terapii talking cure, czyli usiłując rozpisać nieruchome obrazy na linearne narracje, czas traumatycznie przeżywany na czas reparacyjnie opowiedziany - Eliade próbuje zachować w najpierwotniejszej postaci traumatycznego wpływu, z którego Wydarzenie ma czerpać swoją sakralną moc. Polskie święta narodowe znakomicie wpisują się w tę, jak to Eliade sam określał, ,afirmatywnie pogańską” koncepcję sacrum, której pożywki dostarczają wydarzenia skrajnie gwałtowne i kryzysowe, rozbijające ,profaniczny” ład codzienności.

Przypomina mi się w tym kontekście niezwykła rzeźba Stanisława Szukalskiego, artysty przed wojną związanego z poganizującą Zadrugą, potem zaś emigranta tworzącego w Kalifornii (spadkobiercą jego dzieł jest dziś nie kto inny, jak sam Leonardo DiCaprio, syn opiekunów Szukalskiego): rzeźba przedstawiająca Bora-Komorowskiego jako azteckiego demona wojny. Ta z pozoru ekscentryczna kreacja, w której demoniczny Bór unosi się nad hekatombą powstańczych ofiar, odsłania samą esencję polskiej pamięci, która świętuje powstanie warszawskie jako wielką masakrę. Jednak prawdę tę - jak wszystko, co głęboko sakralne, powszechnie ukrywaną - odważył się wypowiedzieć wprost tylko Jarosław Marek Rymkiewicz w swoim fabularyzowanym pamiętniku pt. Kinderszenen. Łącząc Heideggera z Eliadem i Celinem, Rymkiewicz potwierdził intuicję Szukalskiego - że w polskiej, dogłębnie pogańskiej pamięci wielkie wydarzenia sakralizują się tylko poprzez krew;

3 Por. zwłaszcza M. Eliade Sacrum, mit, historia, przeł. A. Tatarkiewicz, PIW, Warszawa 1970 oraz tegoż Mit wiecznego powrotu, przeł. K. Kocjan, KR, Warszawa 1998. 
tak jak w azteckich hekatombach, im więcej się jej przeleje, tym godniejsze stają się upamiętnienia.

Wróćmy jednak do psychoanalizy, która ma tę zaletę, że w odróżnieniu od Eliadego namierza tę zasadę ofiarniczej krwi jako traumatyzującą patologię. Większość wymienionych badaczy, zwłaszcza Dybel i Sowa ${ }^{4}$, najchętniej odwołuje się w swoich analizach do Lacana, mnie jednak wydaje się, że najlepszej psychoanalitycznej teorii zdolnej opisać hiperpatologiczny mechanizm polskiej pamięci historycznej dostarcza Melanie Klein. O ile bowiem Lacan jest tu dość dwuznaczny i równie dobrze (a może nawet lepiej) można by użyć jego koncepcji do apologii polskiego kultu śmierci, o tyle Klein nie pozostawia wątpliwości: tkwienie w pozycji schizoidalno-paranoidalnej, którą cechuje przymus powtarzania, jest absolutnym psychicznym zwyrodnieniem i głównym ,źródłem cierpień”. Pozycja ta jest charakterystyczna dla wczesnej fazy niemowlęcej, w której dopiero co kształtująca się psychika pozostaje w stanie pełnej zależności od matki. Zależność ta rodzi nieustanną frustrację, bo żadna realna matka nie potrafi zaspokoić wszystkich roszczeń niemowlęcia: jest zwykle, jak to określał D.W. Winnicott, brytyjski uczeń Klein, „matką na trzy plus” (good enough mother). Frustracja ta z kolei prowadzi do wybuchów złości i agresji, których obiektem okazuje się ,zła pierś”, czyli życiodajne źródło mleka; ponieważ nie jest ono dostępne cały czas i nie jest też zawsze pełne, niemowlę, wciąż jeszcze mające śladową pamięć ,,prenatalnej rozkoszy", kiedy to było karmione i podtrzymywane w istnieniu bez przerwy, buntuje się przeciw jej brakowi. Agresja fazy schizoidalno-paranoidalnej jest więc w istocie aktem negacji faktu przyjścia na świat; jest próbą odczynienia ,traumy narodzin” (termin Otto Ranka), w wyniku której psyche musi porzucić pleromę rozkosznego bycia w łonie i zostać wydana na obce wpływy zewnętrznego świata: innych, różnicy, zasady rzeczywistości i - last but not least - czasu. W buncie przeciw ,złej piersi" wyraża się więc cała metafizyka Upadku: pragnąc powrócić do bezczasu łona i jego wieczystej zasady przyjemności, psyche odmawia „upadania” w świat i czas. Nie chce konfrontować się z żadną różnicą, bo ta - przynajmniej początkowo - sprawia tylko ból.

4 Por. J. Sowa Fantomowe ciało króla. Peryferyjne zmagania z nowoczesną formq, Universitas, Kraków 2011 oraz P. Dybel Urwane ścieżki. Przybyszewski - Freud - Lacan, Universitas, Kraków 2000.

5 Por. M. Klein Zawiść i wdzięczność, w: tejże Pisma, t. 3, Gdańskie Wydawnictwo Psychologiczne, Gdańsk 2007. 
Największym odkryciem Klein i jej psychoanalizy „relacji z obiektami” jest zdiagnozowanie psychiki niedojrzałej jako zatrzymanej w fazie schizoidalno-paranoidalnej. Niezdolność do przejścia w pozycję depresyjną - gdzie świat przestaje jawić się jako czarno-biała przestrzeń złożona z obiektów albo całkowicie dobrych, albo całkowicie złych - oznacza również brak możliwości dojrzewania: psychika zastyga na mentalnym etapie niemowlęcym, który cechuje naprzemienna repetycja rozkoszy, kiedy to „dobra pierś” przypomina o błogostanie łona, i manii prześladowczej, kiedy to „zła pierś” przypomina o upadku w świat i czas; stanu, w którym panuje błoga, niczym niezakłócona narcystyczna fantazja, oraz stanu, w którym każdy kontakt z zasadą rzeczywistości odbierany jest wprost jako prześladowanie. W przełożeniu na polski kontekst oznaczałoby to, że polska pamięć historyczna, która wykazuje wszystkie cechy utknięcia na mentalnym poziomie niemowlęcym,jest zdolna wytwarzać tylko dwa rodzaje doświadczeń: albo ekstazę wywołaną „spotkaniem z dobrym obiektem" - wodzem, któremu ufa się bezgranicznie, środowiskiem, w którym można poczuć się bezpiecznie niczym w łonie właśnie, lub wydarzeniem dziejowym przedstawionym wyłącznie jako „biała karta” polskiej historii; albo paranoiczny lęk wywołany „spotkaniem ze złym obiektem”, czyli aktywnie prześladowczym „wrogiem polskości” stanowiącym bezpośrednie zagrożenie egzystencjalne.

Zauważmy, że w polskiej wyobraźni sakralno-politycznej - można by ją nazwać uogólnionym mariawityzmem, w którym katolicyzm staje się pogańską religią plemienną towarzyszącą „polskiemu Chrystusowi” w jego krwawych dziejach - święta zawsze noszą cechy „powrotu do łona”, wytwarzając rozkosz opartą na doświadczaniu samowsobnego narodowego narcyzmu. Naród, Kościół (te pozornie męskie rzeczowniki to w istocie żeńskie natia i ecclesia) w polskiej celebrze stają się miejscem prenatalnej błogości, w której święci się cud zawieszenia świata i wszelkiej różnicy. Polskość zapada się wówczas w otchłanie swojej monokulturowej wewnętrzności,jak w swój własny sen-koszmar, który wytwarza tylko język prywatny, dla innych będący niezrozumiałym bełkotem. Gombrowicz słusznie mówił tu o polskim „braku formy", mając na myśli właśnie tę amorfię bezpośrednich odczuć i krótkotrwałych zbiorowych inerwacji, jakie wytwarza wielogłowe polskie ciało „Polak na Polaku”, ugnieceni w jedno narodowe ciasto czy raczej zakalec bez powietrza - gdzie nie rodzi się żadna różnica, dystans, perspektywa. Polski model wspólnotowości, oparty na niemowlęcych wspomnieniach prenatalnych, jest więc istnym proksemicznym koszmarem: gombrowiczowskim kłębowiskiem ciał, wczepionych w siebie tak blisko, że żadne spojrzenie nie 
może przeniknąć mroków tej narodowej orgii. Ślepa tożsamość, niepragnąca żadnego odzwierciedlenia, żadnej refleksji. Najgłębsza patologia wsobności, w której pamięć pełni tylko jedną funkcję: ponownego przywołania traumy, stającej się wówczas pretekstem do odrzucenia świata i powrotu do łona.

Święta te zawierają też nieuchronnie pierwiastki apokaliptyczne: ażeby bowiem wrócić do łona, trzeba najpierw zniszczyć świat. Czy będzie to ,wielka wojna narodów” wieszczona przez Mickiewicza, w której zła obca rzeczywistość wykończy się sama, czy też ofiarnicza śmierć Polaków, dzielnych niemowląt rzuconych na pożarcie Molochowi świata - nie ma to znaczenia. Liczy się sama apokalipsa, czyli wielkie manichejskie NIE niszczące samą zasadę rzeczywistości: życia w świecie, w czasie, w saeculum, gdzie rządzi ambiwalencja i nic nie jest tak po prostu dobre albo złe. Przypomina się tu ,program wyborczy” zadeklarowany przez niejakiego Kononowicza, który samozwańczo, za pośrednictwem internetu, ogłosił się kandydatem na prezydenta Polski. Chaotyczna wyliczanka rozmaitych NIE - ,żeby chuliganów nie było, żeby hałasu nie było, żeby gimnazjów nie było..." - kończyła się jedynie logicznym wnioskiem: „,̇̇eby NICZEGO nie było”. Czasem trzeba wariata, żeby wypowiedział prawdę o oszalałej zbiorowości. Tak jak Szukalski trafił w sedno, prezentując Bora-Komorowskiego jako tanatycznego demona masakry, Kononowicz wypowiedział credo polskiego niemowlęcego apokaliptyzmu: wróćmy do łona, a to coś obcego, ten przebrzydły świat, niech się wreszcie skończy...

Klein twierdzi także, że im większa trauma związana z okresem niemowlęcym, czyli im trudniej przebiega proces konfrontowania dziecka z ,obcym światem” - tym silniejsza skłonność do zahamowania dojrzewania i okopania się psychiki na pozycji schizoidalno-paranoidalnej. Polska pamięć historyczna, skupiona niemal wyłącznie na dziejowych traumach, w których polskość stawała się ofiarą ,wrogiego świata” - vide prezentacja mocarstw europejskich w Księgach pielgrzymstwa polskiego Adama Mickiewicza - działa na dokładnie tej samej zasadzie: podkreślając urazowy charakter konfrontacji z wszelką obcością, zamyka się w fantazmacie samotożsamości, który czerpie z obrazu narcyzmu pierwotnego, kiedy to psychika dziecięca, doznając łonowego błogostanu, nie odróżniała się jeszcze od tego, co od niej inne. Zespół należący do pozycji schizoidalno-paranoidalnej wyznaczają więc takie cechy jak nagie powtórzenie sytuacji traumatycznej, niezdolność do doświadczenia ambiwalencji oraz nietolerancja na najmniejsze choćby wyróżnicowanie. 


\section{Wyjście w czas: polska pamięć krytyczna}

Polska to kraj, w którym dojrzewanie wiąże się ze świadomym wysiłkiem, idącym wbrew spontanicznej tendencji cechującej, jak to określił Stanisław Brzozowski, „Polskę zdziecinniałą”. Chęć przepracowania urazów, w którym znika proste przeciwstawienie „wróg-przyjaciel” i pojawia się gotowość na akceptację ambiwalencji oraz inności, należą do zespołu zwanego przez Malenie Klein pozycją depresyjną - w dzisiejszej Polsce przyjętej wyłącznie przez inteligencję krytyczną, dla której to Brzozowski właśnie pozostaje wciąż aktualnym wzorem.

Według Klein pozycja depresyjna polega przede wszystkim na porzuceniu niemowlęcego narcyzmu i uzyskaniu podmiotowej perspektywy, której pierwszym aktem jest akceptacja świata jako miejsca nieusuwalnej ambiwalencji: świata jako osobnej i zewnętrznej rzeczywistości, która rządzi się swoimi regułami i wobec której psyche musi porzucić sporą część swoich roszczeń. W tej fazie dekompresji dziecko odkrywa, że matka uosabiająca zewnętrze - po raz pierwszy jawiąca się jako obiekt całościowy - nie jest koniec końców taka zła i że jeśli dziecko żyje, to tylko dzięki niej: zależnościowa agresja bezsilnego niemowlęcia ustępuje tu poczuciu winy i wdzięczności za okazaną mu miłość i troskę. Więcej jeszcze, w pozycji depresyjnej zaczyna wyłaniać się także poczucie odpowiedzialności i aktywnego sprawstwa: dziecko czuje, że jego działania także mają wpływ na rzeczywistość - że może zranić i skrzywdzić otoczenie, które dało mu życie - i odtąd nie czuje się już tylko ofiarą. Nie wali już w świat jak w bęben, zaczyna rozumieć kruchą naturę wszystkiego, co istnieje poza nim; zaczyna współodczuwać, a tym samym współuczestniczyć. Staje się częścią świata.

„Stać się częścią świata”: w ten sposób można by streścić marzenie, jakie zawsze przyświecało Brzozowskiemu, obsesyjnie ogarniętemu pragnieniem „dziejowego dojrzewania". Wiecznie niepogodzony z polskim modelem schizoidalno-paranoidalnym, Brzozowski chciał dojrzeć do pozycji historycznego sprawstwa i odpowiedzialności: chciał, by Polacy stali się elementem zachodniego procesu cywilizacyjnego i dołączyli do grona tych narodów, które proces ten świadomie kultywują. Adam Lipszyc, używając bardzo podobnych instrumentów krytycznych, czyli także psychoanalitycznego aparatu Melanii Klein, mówił tu o przezwyciężeniu niemowlęcej pozycji wobec Unii Europejskiej, co doskonale oddaje życzenie Brzozowskiego, by Polska poczuła się wreszcie współodpowiedzialną częścią Zachodu, a nie tylko zależną od niego wieczną ofiarą. Tak bowiem jak niemowlęca agresja jest tylko rewersem bezsilności, tak też obecne polskie napaści na Unię zdradzają poczucie, 
że żaden atak przypuszczony na unijne „matczyne ciało” nie jest w stanie jej zaszkodzić; tak jak gryzące i kopiące niemowlę czuje się całkiem bezradne wobec matki, która nadal karmi bez względu na jego akty agresji, Jarosław Kaczyński będzie rzucał pod adresem Unii najgorsze oskarżenia, jednocześnie oczekując, że ta nadal będzie „płacić”. Niemowlęciu wszystko wolno, bo i tak nic nie może. Wściekłe czy nie, jest skazane na pierś, którą kąsa.

Dojrzewanie zatem to wyjście z patologii zależności, ale - z pozoru paradoksalnie - przez uznanie faktu zależności. To depresyjne rozpoznanie, że nie jest się pępkiem świata, a jedynie częścią większej całości, oddziałuje też na konkurencyjny model pamiętania, w którym narcystyczne roszczenia Polaków do prezentowania się jako kosmiczna ofiara albo „Chrystus narodów" - będące prostym odwróceniem, a zarazem kontynuacją niemowlęcego poczucia wszechmocy i wszechważności - zostają gruntownie przepracowane i ustępują trzeźwiejszemu poczuciu peryferyjności. O ile bowiem polska pozycja schizoidalno-paranoidalna stawia Polskę nieuchronnie w centrum wszechświata - o tyle pozycja depresyjna wypracowuje obraz Polski jako kultury peryferyjnej, zależnej od wzorców wytworzonych w bardziej ośrodkowych cywilizacjach, czyli, jak mówi Klein, skazanej na to, by „uczyć się od innych”. Dla Brzozowskiego nie ulegało wątpliwości, że Polska musi raz wreszcie przestać nasładzać się samą sobą „ku pokrzepieniu serc” i wejść w okres nauki, której w żadnym sensie nie utożsamiał z zasadą „ślepej imitacji”, tak chętnie przypisywanej dziś przez prawicę polskim mieszczańskim „lemingom”. Tak jak podmiot w pozycji depresyjnej wie, że nauka to żadna hańba - czyli że dziecko przyszło na świat później niż rodzice, którzy „byli tu wcześniej” i lepiej wiedzą, jak sobie ze światem radzić - tak Brzozowski nie czuł peryferyjnego wstydu wobec kultur nowoczesności pierwotnej, w tym zwłaszcza brytyjskiej. Chciał pełnymi garściami czerpać z kulturowej samowiedzy Hume’a, Blake’a, Byrona i Mereditha - i wiele z tego, co twórczo przyswoił, mogłoby pomóc w procesie dojrzewania choćby polskiemu paradygmatowi romantycznemu. Ucząc się od Brytyjczyków innego modelu pamiętania - opartego na intensywnie sprawczym uczestnictwie w świecie i czasie - Brzozowski miał nadzieję, że przysłuży się dorastaniu także polskiej duszy, że przyuczy ją do bardziej refleksyjnego sposobu myślenia o własnej historii, w której bierna zależność wobec Zachodu nierzadko kompensowana była brutalną wyższością kolonizacyjną wobec narodów uznawanych za jeszcze bardziej cywilizacyjnie zacofane.

Wbrew temu, co twierdzą dziś spece od dumnego „wstawania z kolan”, pozycja depresyjno-peryferyjna,jaką Brzozowski zaleca Polakom, nie ma w sobie 
nic z upokorzenia. Po pierwsze, to zwykła konstatacja faktyczna: polska cywilizacja, z powodów nie zawsze od niej zależnych, jest wtórna w stosunku do zachodniej modernizacji i jeśli chce w niej uczestniczyć, to musi tę kondycję opóźnienia uznać (chyba że nie chce, ale wtedy naprawdę musi wypisać się z Unii). Po drugie, to równie zwykłe wyjście z dziecinnego narcyzmu, kiedy to własna historia przestaje jawić się jako pasmo szczególnych i niezwykłych zdarzeń - wręcz cudownych, jak w przypadku „cudu nad Wisłą” albo „cudu Solidarności" wymodlonego przez polskiego Papieża - a odsłania się jako typowa historia narodów słabych, padających łatwym łupem wszelkiego rodzaju najeźdźców. A po trzecie, to także szansa, by z polskiej pamięci wyłonić naprawdę to, co istotne: nie kolejne nieudane powstania, masakry i bezsensowne hekatomby, ale doświadczenia swoiste, nieznane bardziej fortunnym kulturom pierwszego Zachodu. W tym przede wszystkim pamięć o komunizmie.

I tu zataczam koło, wracając do mojego punktu wyjścia: gdybym bowiem miała wyobrazić sobie model polskiej pamięci dojrzałej, to byłaby nim wytężona próba przepracowania doświadczenia komunizmu, zorientowana nie na przeszłość, lecz na przyszłość - czyli nie tyle na próby zadośćuczynienia (bo oddać sprawiedliwość każdej z milionów ofiar po prostu nie sposób), ile na nasze przyszłe odpowiedzialne zaangażowanie w projekcie zachodniej modernizacji, krytyczne wobec wszelkich społecznych radykalizmów. Jeśli gdzieś nasza pamięć mogłaby okazać się uniwersalnie ważna i przydatna, to tylko $\mathrm{w}$ tym jednym aspekcie: $\mathrm{w}$ memento mocnym głosem sprzeciwiającym się podtrzymywaniu „idei komunizmu” jako wiecznie żywej i w żadnym sensie nieumniejszonej przez brudną materię realnego socjalizmu. Bo jeśli o czymś warto z polskiej historii pamiętać i nad pamięcią tą pracować, to tylko po to, by z mocą autopsji przestrzegać innych przed pójściem do końca i pełną realizacją najszlachetniejszej nawet utopii.

Uważam wręcz, że pamięć komunizmu powinna stać się naszą misją jako inteligencji krytycznej czerpiącej z dziedzictwa Brzozowskiego; świadectwem naszej dojrzałej pozycji depresyjnej nie tylko w stosunku do prawicowych roszczeń polskiej tradycji, ale także w odniesieniu do lewicowych utopizmów o zasięgu uniwersalnym. A nade wszystko powinniśmy pracować nad tym, by trauma komunizmu nie została bez reszty zawłaszczona przez obrazkową pseudopamięć polskich prawicowych obrzędów. Jeśli tak się stanie, to zmarnujemy jedyną być może szansę wybicia się na prawdziwie refleksyjną podmiotowość. Miarą podmiotowej dojrzałości jest bowiem dobrze przepracowana pamięć, dzięki której podmiot potrafi swoją historię opowiedzieć tak, by inni mogli wyciągnąć lekcję z jego opowieści. 


\section{Abstract}

\section{Agata Bielik-Robson}

INSTITUTE OF PHILOSOPHY AND SOCIOLOGY OFTHE POLISH ACADEMY OF SCIENCES, UNIVERSITY OF NOTTINGHAM

Memory-a Pharmacon

This essay examines the pathologies of Polish memory through Melanie Klein's psychoanalytical theory. Bielik-Robson suggests that the majority of what is seen as historical memory in contemporary Poland is no memory at all but a compulsion to repeat, reminiscent of the dark ritual of an ever-returning trauma. It is of course risky to extrapolate from psychoanalytical methods to collective subjects, but this essay attempts to describe the assumptive subject of the Polish collective as a Kleinian'angry infant' in the paranoid-schizoid position. This arrested development results in a falsely passive experience of dependency as well as a complete inability to work through trauma. To develop this ability, however, turns out to be a necessary condition for the formation of memory in the strict sense.

\section{Keywords}

individual and collective memory, repetition compulsion, trauma, Melanie Klein, psychoanalysis, angry infant 